\title{
THE INFLUENCE OF PARENTING, SELF-EFFICACY, AND ENTREPRENEURIAL INTEREST TOWARD THE LEARNING MOTIVATION OF CREATIVE PRODUCTS AND ENTREPRENEURSHIP OF CULINARY MANAGEMENT VOCATIONAL SCHOOL STUDENTS
}

\author{
Naning Yulianti Antonia ${ }^{1 *}$, Badraningsih Lastariwati ${ }^{1}$ \\ ${ }^{1}$ Universitas Negeri Yogyakarta \\ Jl. Colombo No. 1, Karangmalang, Depok, Sleman, Yogyakarta 55281, Indonesia
}

\begin{abstract}
This study aims to reveal the effects of (1) parenting, (2) self-efficacy, (3) entrepreneurial interest, and (4) parenting, self-efficacy, and interest in entrepreneurship simultaneously on the motivation to learn creative products and entrepreneurship in class XII vocational school of Catering Services Department in Magelang. This research is ex-post facto research. The research population was 201 students of the Catering Services Department from two vocational schools in Magelang. The sample consisted of 127 students who were taken using the proportional random sampling technique. The data analysis technique used descriptive analysis and regression analysis. The results showed that: Parenting, self-efficacy, and interest in entrepreneurship were able to predict learning motivation with an effective contribution to parenting (5.15\%, high category); self-efficacy (3.63, low category); interest in entrepreneurship (32.80\%, very high category). The coefficient of determination (R2) is $0.416(41.6 \%)$, which means that $41.6 \%$ of students' motivation to learn creative products and entrepreneurship in class XII of the Catering Services Department are influenced by parenting, self-efficacy, and interest in entrepreneurship, while the remaining $58.4 \%$ is influenced by other variables that are not examined in this study.
\end{abstract}

Keywords: interest in entrepreneurship, learning motivation, parenting, self-efficacy

How to cite: Antonia, N., \& Lastariwati, B. (2020). The influence of parenting, selfefficacy, and entrepreneurial interest toward the learning motivation of creative products and entrepreneurship of culinary management vocational school students. Jurnal Pendidikan Vokasi, 10(3), 315-323. doi:https://doi.org/10.21831/jpv.v10i3.32428

*Corresponding Author: Naning Yulianti Antonia@naningyulianti.2018@student.uny.ac.id -Department of Technology and Vocational Education, Graduate School, Universitas Negeri Yogyakarta

Jl. Colombo No. 1, Karangmalang, Depok, Sleman, Yogyakarta 55281, Indonesia 


\section{INTRODUCTION}

Adolescence is a transitional period from childhood to adulthood, that is, children do not want to be treated as children, but physically they cannot be said as adults. Adolescence may be a defenseless period, particularly the issue of juvenile delinquency. The causes of juvenile delinquency include heredity, identity problems, community influence and family experiences. As an illustration within the case of a young battle in Magelang, approximately 40 vocational students were included in a brawl (Fitriana, 2019). This case should be a family concern, how to reduce juvenile delinquency at this time with legitimate care.

The role of parents is crucial. Based on Law of the Republic of Indonesia No. 23 of 2002 article 26 concerning Child Protection, that parents have the obligation and responsibility to care for, nurture and educate, protect children, foster children according to their abilities, talents and interests and prevent child marriages. The role of parents can be well-applied if the parental care has a good influence too, especially in the children's development. One of the problems which is currently being debated in some research that focuses on family matters is how to attain optimal parenting in educating children. One of the positive supports that can be given by the family is to motivate the children, particularly to provide motivation in learning.

According to Oyeku et al. (2014) in a research article about the influence of family, motivation and personality towards entrepreneurial interest through self-efficacy reveal that the variable that can foster motivation or interest is self-efficacy (Kurniawan, et al., 2016, p. 100). Self-efficacy is a person's belief to accomplish the task. Self-efficacy is influenced by the conceptual factors such as education and past experiences. The level of efficacy will affect a person's enthusiasm; the low level of efficacy considers someone incapable to do something around him whereas someone with high level of efficacy in any situation will try hard to overcome the challenges (Ghufron \& Risnawita, 2012, p. 76). The level of student's success depends on the enthusiasm and motivation (self-efficacy) within the students themselves. This will have a huge impact in learning process, when the learning motivation is high then the learning outcome will be high too, however if the learning motivation is low, the learning outcome will be low. Self-efficacy has an effect on entrepreneurial interest, research revealed by Farida and Nurkhin (2016, p. 273).

The interest arises when someone has the feeling of like and dislike to do the accomplished task. Interest is not carried from birth, interest is influenced by physical factors, psychological factors and environmental factors. The interest to be researched is the level of entrepreneurial interest of the XII graders vocational school in Magelang. The way to foster entrepreneurial interest is by developing within them an interest in entrepreneurship. With an interest in them, students are encouraged to learn knowledge related to entrepreneurship for the better. It is expected that students will have self-awareness and enthusiasm to foster entrepreneurial attitudes.

The entrepreneurial interest from the respondents, especially students of class XII Catering Services Department in Magelang, which is one of the tourist cities that is quite crowded with tourists. Business opportunities in the culinary field are the main attraction, so this is a very good opportunity to develop. This research is expected to draw a clear picture of how to see the influence of parenting, self-efficacy or students' self-confidence as well as their inner interests so that they can have the learning motivation, especially entrepreneurial learning and creative products of XII graders of Catering Service Department in Magelang.

\section{Parenting}

Parenting is a style of taking care applied by parents in various ways and understandings. The definition of parenting based on Indonesian Dictionary is the process, method, action, and parenting style. Meanwhile, Masud Hoghughi, Professor of the Faculty of Psychology, University of Hull America in Nefrijanti (2018) assumes that parenting is a relationship between parents and children that is multi-dimensional and can grow steadily and it also includes a variety of activities with various goals, namely, the child can develop optimally and survive well, therefore, parenting style includes physical care, emotional care and social care.

According to Baumrind (1971) in Santrock (2007, p. 167), parenting has four styles formed from two dimensions: dimensions of responsiveness and demandingness. This parenting style is 
also popularized by Marcoby and Martin (1983) in Sutanto and Andriyani (2020, p. 108), including: (a) authoritarian care, where the child must obey all the rules set by the parents. Parents will apply high discipline to their children. (b) Permissive care, where parents give complete freedom to their children, without giving any rules to family members, including children. (c) Democratic/ authoritative care, where parents act as the determinants of rules, but children are still given the opportunity to know and understand the rules that have been made by parents. (d) Neglect, that is, parenting style that is too indulgent, where parents are not very involved in the child's life. Pradani (2017) in Sutanto and Andriyani (2020, p. 15) claims that parents should apply the positive parenting style. Parental care is said to be positive when parents can think positively about their children. This type of parenting will foster self-concept and positive thinking in children. Negative parenting style is parenting style that often performs negative actions in parenting, for example hitting, ignoring, humiliating oneself, being unfair, and so on. The characteristics of positive parenting style according to Faber (1980), Hansen (1982), Jams (1985), and Gordon (2000) in Sunarty (2015, pp. 1724) are reasonable parents, encouraging parents, con-sistent parents and responsible parents. According to González et al. (2016), with positive parenting, parents show the better control as shown by quarrels, fights, and reprimand against children decreased significantly.

\section{Self Efficacy}

The definition of self-efficacy according to Bandura (1997, p. 3) is a belief about the ability to organize and take a series of actions needed to achieve their beliefs. Meanwhile, according to Woolfolk (2007) in Marini and Hamidah (2014), self-efficacy is a person's assessment of himself or his level of confidence regarding how much his or her ability to do a certain task to achieve certain results. There are four sources of self-efficacy: (1) mastery experience, it will foster self-efficacy in oneself, while failure can be overcome with certain efforts that can strengthen self-motivation if someone can find meaning from the experience. (2) Vicarious experience is the experience of the success of others with comparable abilities in doing tasks that will increase individual selfefficacy. (3) Verbal persuasion is more directed by providing advice and guidance so it can increase confidence in one's abilities. (4) Physiological state is a physical tension in a stressful situation, seen as a sign of incapacity due to weakening of individual work. In addition, self-efficacy is divided into three dimensions: (1) level, related to the level of difficulty experienced by individuals in completing tasks, with different ability limits for each individual; (2) strength, related to strength or belief about the abilities that people have - weak expectations are easily shaken by unsupportive experiences, while steady expectations will encourage individuals to stay in higher dimensions; (3) generality, related to the broad field of behavior where individuals feel confident in their abilities.

\section{Entrepreneurial Interest}

The definition of interest, according to Slameto in Marini and Hamidah (2014, p. 201), is that there is a feeling of preference and interest in something or an activity, without being asked. According to Winkel and Hastuti (2004), it is a rather sedentary tendency for someone to feel attracted to a certain field and feel happy to be involved in various activities in that field. Daryanto $(2012$, p. 7) believes that entrepreneurship is an effort to create added value by combining sources through new and different ways to win the competition. Meanwhile, according to Zimmerereal (2008) in Wijaya (2017, p. 21), an entrepreneur is someone who creates a new business by facing uncertainty and risk to achieve profits and business growth by identifying significant opportunities and using the required resources.

Entrepreneurial interest is the desire or interest and ability of students in entrepreneurship, especially the students of XII grade of Catering Services Department in Magelang. According to Meredith in Marini and Hamidah (2014), there are six characteristics of entrepreneurship: having self-confidence, being task-oriented, courageous to take risks, socializing with others, innovative and creative and future-oriented. These interests will grow when there is motivation. Learning motivation needs to be cultivated as an effort to support learning, especially learning entrepreneurship and creative products. Learning motivation is students' willingness in the learning process, especially in entrepreneurship lessons and creative products. Learning creative products and entrepre- 
neurship is a learning process in creating new ideas as a form of business in a new work that is occupied. There are many factors that can influence the interest in entrepreneurship, one of which is developing entrepreneurship education and teachers as role models for building interest in entrepreneurship, as indicated by a research conducted by San-Martín et al. (2019). This is in line with research disclosed by Iwu et al. (2019) which also explains that entrepreneurship education can influence entrepreneurial interest in South Africa. Entrepreneurial interest is a very important part of building learning motivation which is also related to entrepreneurship education.

Entrepreneurial interest is generally influenced by (1) the ideals and aspirations of students, in this case the aspirations will strengthen motivation; (2) abilities coupled with student desires; (3) the student's condition is good (physically and mentally healthy) so that it is easy to focus attention in learning; and (4) students' environmental conditions will increase children's interest or enthusiasm in learning. Therefore, this study aims to reveal the effects of: (1) parenting, (2) self-efficacy, (3) interest in entrepreneurship, and (4) parenting, self-efficacy and interest in entrepreneurship simultaneously on the motivation to learn creative products and entrepreneurship in class XII vocational school of Catering Services Department in Magelang.

\section{RESEARCH METHOD}

This study is an ex-post facto research, since it only reveals the symptoms that occur as they were and reveals the factors that influence the independent variable on the dependent variable. This research is a descriptive correlational study according to the problem with a quantitative approach.

\section{Research Setting}

This research was conducted on February 2020 till April 2020. The research subjects were XII graders of vocational school of Catering Service Department in Magelang, namely, Sekolah Menengah Kejuruan (SMK) Negeri 3 Magelang and SMK Pius X Magelang.

As shown in Table 1, the research population was 201 students from grade XII of Catering Service Department in Magelang. The sample in this study was 127 students collected using proportional random sampling technique, where each school with a diverse number of respondents was tested based on the extent of the number of respondents in each of these schools (Sugiyono, 2017, p. 120). The determination of the number of samples was based on Isaac and Michael's table at an error rate of $5 \%$.

Table 1. Population Data and Research Sampling

\begin{tabular}{ccc}
\hline Schools' Name & Population & Sample \\
\hline SMK N 3 MGL & 108 & 68 \\
SMK Pius X MGL & 93 & 59 \\
Total & 201 & 127 \\
\hline
\end{tabular}

This study used questionnaires and document review as the data collection techniques. The questionnaire with the consideration that the number of respondents was quite large and spread across several schools in Magelang was used. The validity test used content validation and construct validity. Reliability test was using Alpha Cronbach formula. The instrument can be said to be reliable if the Cronbach Alpha coefficient is greater than 0.70 (Mardapi, 2008, p. 125).

The data analysis technique used descriptive analysis and regression analysis. Descriptive analysis provided an overview of the data seen from the mean, median, mode, standard deviation, maximum, minimum, range using SPSS 20.0 for windows software to be analyzed.

\section{RESULTS AND DISCUSSION}

\section{Parenting}

The results of the parenting analysis show that 20 students $(15.7 \%)$ were in the very high category, 65 students $(51.2 \%)$ were in the high category, 36 students $(28.3 \%)$ were in the low cate- 
gory, and six students $(4.7 \%)$ had a very low category. In term of the parenting variable, the mean (105.59) result of the descriptive analysis is compared to the category distribution, so the mean parenting lies in the high value range. Thus, it is stated that the respondents' parenting is in the high category. The results of data analysis illustrated by the frequency histogram is shown in Figure 1.

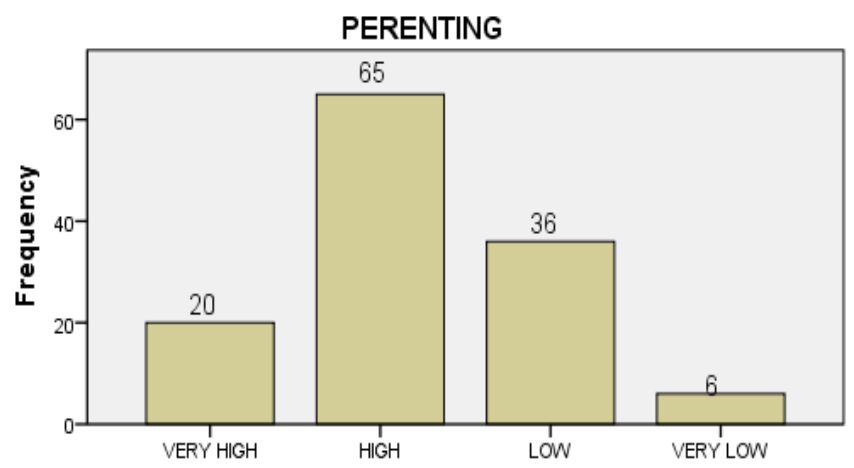

Figure 1. Parenting Frequency Histograms of XII Grade of Catering Service Department of Vocational School Students in Magelang

The high parenting tendency implies that parenting style has provided positive motivation in learning. This support includes examples of exemplary action, being consistent with responsibility and obeying common provisions, positive habituation, and building communication with children without violence. This parenting has a good impact on children, so they are motivated to learn well. This research is supported by previous research conducted by Delima and Usman (2019). This study confirms that there is a positive and significant relationship between interest in learning, parental attention and learning motivation towards student achievement in class XI SMA in Jakarta. It is also in line with the research revealed by Kaukab $(2016$, p. 72) that parental involvement positively increases children's learning motivation for the better.

\section{Self Efficacy}

The results of the self-efficacy data analysis show that there were 18 students $(14.2 \%)$ in the very high category, 37 students $(29.1 \%)$ in the high category, 46 students $(36.2 \%)$ in the low category and 26 students $(20.5 \%)$ in very low category. The mean value of 46.51 results of descriptive analysis is compared with the distribution of categories, so self-efficacy lies in the range of values in the low category. Thus, it is stated that the self-efficacy of the respondents is included in the low category. The results of data analysis illustrated by the frequency histogram presented in Figure 2.

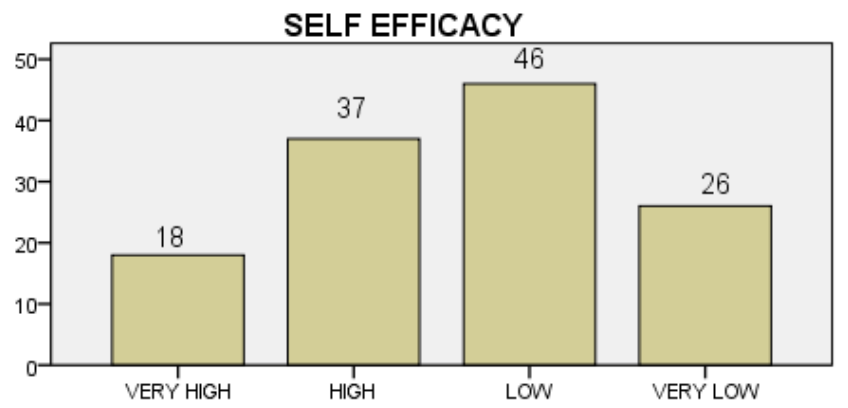

Figure 2. Histogram of Frequency of Self Efficacy of XII Grade of Catering Service Department of Vocational School Students in Magelang

The tendency of self-efficacy from the respondents has a low category, meaning that the belief students have is less confident in their ability to motivate themselves, especially in term of learning, confidence in self-strength and self-ability to motivate learning with all the challenges 
that exist. In addition, Bandura (1997) argues that the characteristics of individuals who have high self-efficacy are the individuals feel confident that they feel able to deal effectively with the events or situations they are facing, are diligent in completing tasks, believe in their own abilities and perceive difficulties as a challenge. The results of this study reveal that the average student still did not have the confidence to motivate themselves, especially in terms of learning. This study supports the previous research conducted by Robih et al. (2017) that self-efficacy significantly affects learning motivation. It is also in line with Kuo et al. (2017, p. 131) who assert that "students with higher levels of research self-efficacy also tend to have higher research productivity".

\section{Entrepreneurial Interest}

The results of data analysis on entrepreneurial interest showed that there were 68 students $(53.5 \%)$ in the very high category; as many as 44 students (34.6\%) in the high category; as many as 13 students $(10.2 \%)$ in the low category and two students $(1.6 \%)$ in the very low category. The mean (51.00) result of the descriptive analysis compared to the distribution of categories lies at a very high value. Thus, it can be stated that the interest in entrepreneurship among the respondents is in the very high category. The results of data analysis illustrated by the frequency histogram are presented in Figure 3.

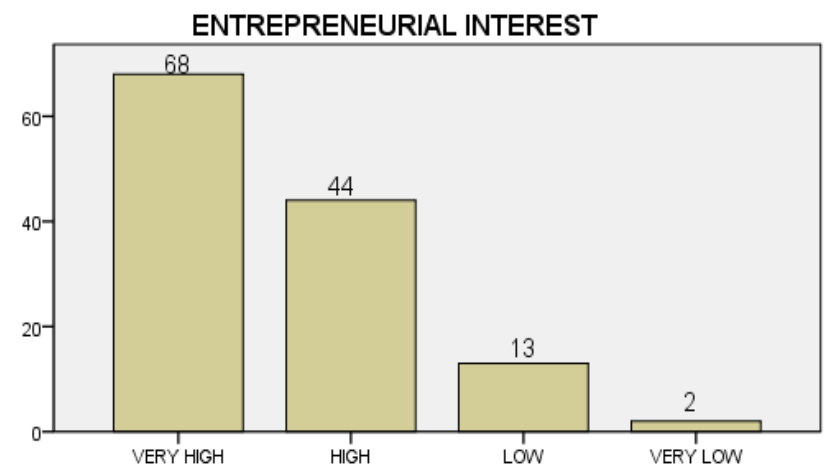

Figure 3. Histogram of Frequency of Entrepreneurial Interest in XII Grade of Catering Service Department of Vocational School Students in Magelang

The tendency of very high interest in entrepreneurship from the respondents has very high curiosity about entrepreneurship and willingness to be entrepreneurial. This study supports the previous research conducted by Widjaja (2019). It is also in line with research conducted by Nurmaliza et al. (2018, p. 43) which confirmed that entrepreneurship education and the family environment have a positive and significant influence on entrepreneurial interest. The influence of interest in entrepreneurship in this study is learning motivation, where in addition to learning motivation, entrepreneurship education also has a role in developing interest.

\section{Learning Motivation}

The results of the data analysis on entrepreneurial learning motivation and creative products showed that there were two students $(1.6 \%)$ in the very high category; as many as 17 students (13.4\%) in the high category; as many as 90 students (70.9\%) in the low category and 18 students $(14.2 \%)$ in the very low category. The mean value (52.12) of the results of the descriptive analysis compared to the distribution of categories lies in the low value range. Thus, it can be stated that the motivation to learn entrepreneurship and the creative products of respondents is in the low category. The data analysis is illustrated through the frequency histogram, presented in Figure 4.

The low tendency of motivation to learn entrepreneurship and creative products from the respondents means that they are lacking, in terms of students' lack of knowledge, less desire and curiosity, encouragement of the need and persistence in learning entrepreneurship and products creative is also lacking. 


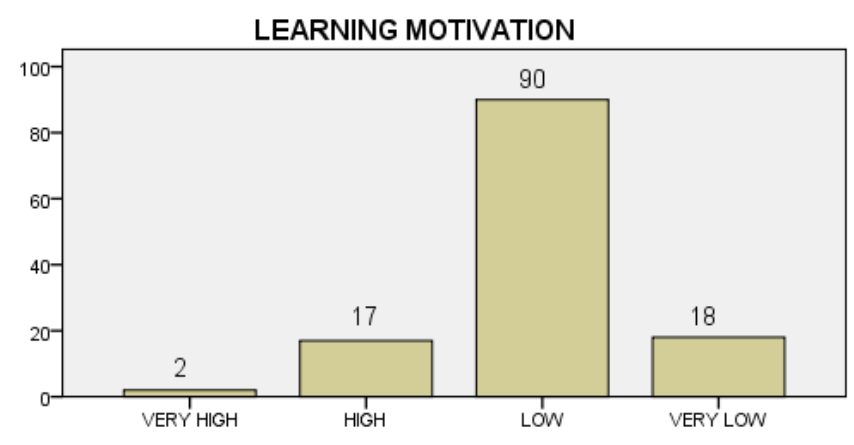

Figure 4. Histogram of Frequency of Entrepreneurship Learning Motivation and Creative Products of XII Grade of Catering Service Department of Vocational School Students in Magelang

\section{Results of Hypotheses}

The results of the first hypothesis test with simple regression analysis showed that the parenting variable had an effect on the motivation to learn entrepreneurship and the creative products of the respondents. The results of data analysis show that the significance value is as large as 0.000 $<0.05$ at the $5 \%$ significance level. The results of the analysis also show that the correlation value (r) is positive, which is 0.403 , so it can be stated that the parenting variable has a positive effect on entrepreneurial learning motivation and creative products of the respondents. This is in line with the research conducted by Delima and Usman (2019). The results of this study confirm that there is a positive and significant influence between classroom learning, parental attention, learning motivation, and learning outside the classroom using a mentor at SMK Jakarta, the effect is $82.7 \%$. Parenting in the family is a key element in motivating children's learning as well as shaping their personality traits. Motivation to learn will grow along with the parenting patterns that are applied. Positive parenting according to Sutanto and Adriyani (2020, p. 23) is care that is based on love, mutual respect, and stimulates children's growth and development. One example of giving rewards to children who get good grades, this is one way to motivate children to learn.

The results of the second hypothesis with simple regression analysis indicate that the selfefficacy variable has a positive effect on the motivation to learn entrepreneurship and the creative products of the respondents. It can be read from the results of data analysis that the significance value is $0.000<0.05$ at the $5 \%$ significance level. The results of the analysis also show that the value of the correlation coefficient ( $r$ ) is positive, which is 0.454 , so it can be stated that the self-efficacy variable has a positive effect on the learning motivation of the respondents. Someone who has high self-efficacy will also have high learning motivation. A research by Robih et al. (2017) show that self-efficacy affects the motivation to learn office automation skills for class $\mathrm{X}$ administrative competence at private vocational schools in North Surabaya. Self-efficacy is a belief in yourself, when you do not have confidence in yourself, you cannot achieve your existing desires.

The results of the third hypothesis test with simple regression analysis show that the variable interest in entrepreneurship has a positive effect on the motivation to learn entrepreneurship and the creative products of the respondents. It can be read from the results of data analysis that the significance value is $0.000<0.05$ at the $5 \%$ significance level. The results of the analysis also show that the correlation coefficient (r) is positive, which is 0.626 , so it can be stated that the Entrepreneurial Interest variable has a positive effect on entrepreneurial learning motivation and creative products of the respondents. Entrepreneurial interest grows because of inner motivation, Hurlock (1978) in Farida and Nurkhin (2016, p. 277) emphasizes that interest is a strong motivation to learn. With the interest in entrepreneurship, students are able to work independently by creating their own jobs. According to Widjaja (2019, p. 46), there is a significant influence between learning motivation and interest in entrepreneurship in XYZ school, West Jakarta. It is also in line with a research conducted by Hutagalung et al. (2017, p. 345) showing that partially, the variables of entrepreneurship education and family environment (care) have a positive value and have a significant impact on students' entrepreneurial motivation. 
The results of the multiple regression analysis show that parenting (parenting), self-efficacy, and interest in entrepreneurship have a positive effect together on entrepreneurial learning motivation and creative products of the respondents. This can be read from the results of the $\mathrm{F}$ test which shows a value of 29.183 compared to the value of 2.68 at the $5 \%$ significance level. The results of the analysis also show that the value of the correlation coefficient (r) is positive, which is equal to 0.416 , thus, it can be stated that parenting variables, self-efficacy and interest in entrepreneurship have a positive effect on the learning motivation of the respondents.

\section{CONCLUSION}

Based on the results of data analysis and the discussion previously presented, there are four conclusions in this study. Partially that: (1) parenting has an effective contribution of $5.18 \%$ in the high category, (2) self-efficacy has an effective contribution of $36.22 \%$ in the low category, (3) interest in entrepreneurship has an effective contribution of $53.54 \%$ is in the very high category, (4) motivation to learn entrepreneurship and creative products has an effective contribution of $70.87 \%$ in the low category.

Based on the results of the hypothesis test, it can be concluded as follows: there is a positive and significant influence of parenting on entrepreneurial learning motivation and creative products, with the correlation coefficient $(\mathrm{rx} 1, \mathrm{y})$ is 0.403 and $\mathrm{p}<0.05$; There is a positive and significant effect of self-efficacy on motivation to learn entrepreneurship and creative products, with a correlation coefficient ( $\mathrm{rx} 2, \mathrm{y})$ of 0.454 and $\mathrm{p}<0.05$; there is a positive and significant effect of interest in entrepreneurship, there is motivation to learn entrepreneurship and creative products, with the correlation coefficient $(\mathrm{rx} 3, \mathrm{y})$ is 0.626 and $\mathrm{p}<0.05$; and there is a positive and significant effect together from parenting (parenting), self-efficacy, interest in entrepreneurship, there is entrepreneurial learning motivation and creative products with a correlation coefficient value $(\mathrm{Rx} 1, \mathrm{x} 2, \mathrm{x} 3, \mathrm{y})$ is 0.645 . The strong influence of parenting variables, self-efficacy and interest in entrepreneurship is indicated by the magnitude of the R2 value, namely 0.416 . Thus, it can be said that the effective contribution of the three independent variables to student learning motivation is $41.58 \%$.

\section{REFERENCES}

Bandura, A. (1997). Self efficacy. Stanford University.

Daryanto, D. (2012). Pendidikan kewirausahaan. Gava Media.

Delima, A., \& Usman, O. (2019). Effect of learning interests, attention parents, learning motivation and learning outside of school mentoring achievement of class X SMK in Jakarta. Journal of Education, Forthcoming. http://dx.doi.org/10.2139/ssrn.3415304

Farida, S., \& Nurkhin, A. (2016). Pengaruh pendidikan kewirausahaan, lingkungan keluarga, dan self efficacy terhadap minat berwirausaha siswa SMK program keahlian Akuntansi. Economic Education Analysis Journal, 5(1), 273-289. Retrieved from https://journal.unnes. ac.id/sju/index.php/eeaj/article/view/10003

Fitriana, I. (2019). Terlibat tawuran yang tewaskan 1 siswa, 3 pelajar SMK diamankan polisi. Kompas. Retrieved from https://regional.kompas.com/read/2019/02/01/17270241/terlibattawuran-yang-tewaskan-1-siswa-3-pelajar-smk-diamankan-polisi?page=all

Ghufron, M. N., \& Risnawita, R. (2012). Teori-teori psikologi. Ar-Ruzz Media.

González, R. A. M., Ruiz, B. R., Blanco, L. Á., \& Vázquez, C. B. (2016). Evidence in promoting positive parenting through the Program-Guide to Develop Emotional Competences. Psychosocial Intervention, 25(2), 111-117. https://doi.org/10.1016/j.psi.2016.04.001

Hutagalung, B., Dalimunthe, D. M. J., Pambudi, R., Hutagalung, A. Q., \& Muda, I. (2017). The effect of enterpreneurship education and family environment towards students' entrepreneurial motivation. International Journal of Economic Research, 14(20), 331-348. 
Iwu, C. G., Opute, P. A., Nchu, R., Eresia-Eke, C., Tengeh, R. K., Jaiyeoba, O., \& Aliyu, O. A. (2019). Entrepreneurship education, curriculum and lecturer-competency as antecedents of student entrepreneurial intention. The International Journal of Management Education, 19(1), 100295. https://doi.org/10.1016/j.ijme.2019.03.007

Kaukab, S. R. (2016). The impact of parent/family involvement on student learning outcomes. International Journal of Research - Granthaalayah, 4(10), 72-81. https://doi.org/10.5281/ zenodo. 164925

Kuo, P. B., Woo, H., \& Bang, N. M. (2017). Advisory relationship as a moderator between research self-efficacy, motivation, and productivity among counselor education doctoral students. Counselor Education and Supervision, 56(2), 130-144. https://doi.org/10.1002/ ceas. 12067

Kurniawan, A., Khafid, M., \& Pujiati, A. (2016). Pengaruh lingkungan keluarga, motivasi, dan kepribadian terhadap minat wirausaha melalui self efficacy. Journal of Economic Education, 5(1), 100-109. Retrieved from https://journal.unnes.ac.id/sju/index.php/jeec/article/view/ 13023

Law of the Republic of Indonesia No. 23 of 2002 concerning Child Protection. (2002).

Mardapi, D. (2008). Teknik penyusunan instrument tes dan non tes. Mitra Cendikia.

Marini, C. K., \& Hamidah, S. (2014). Pengaruh self efficacy, lingkungan keluarga, dan lingkungan sekolah terhadap minat kewirausahaan siswa SMK Jasa Boga. Jurnal Pendidikan Vokasi, 4(2), 195-207. https://doi.org/10.21831/jpv.v4i2.2545

Nefrijanti, N. (2018). Definisi dan pendapat para ahli tentang pengasuhan (parenting). Pusatkemandiriananak.com. Retrieved from https://pusatkemandiriananak.com/definisi-danpendapat-para-ahli-tentang-pengasuhan-parenting/

Nurmaliza, N., Caska, C., \& Indrawati, H. (2018). Analysis of factors affecting entrepreneurial intersest of vocational high school students in Pekanbaru. Journal of Educational Sciences, 2(2), 42-51. Retrieved from https://jes.ejournal.unri.ac.id/index.php/JES/article/view/5735

Robih, M. W., Suratman, B., \& Soesatyo, Y. (2017). The effects of self efficacy, the role of teacher, parents participation to student's learning motivation at vocational high school North Surabaya. Journal of Economics and Economic Education Research, 18(2). Retrieved from https://www.abacademies.org/articles/the-effects-of-selfefficacy-the-role-of-teacherparents-participation-to-students-learning-motivation-at-vocational-high-school-no6777.html

San-Martín, P., Fernández-Laviada, A., Pérez, A., \& Palazuelos, E. (2019). The teacher of entrepreurship as a role model: Students' and teachers' perception. The International Journal of Management Education, 19(1), 100358. https://doi.org/10.1016/j.ijme.2019.100358

Santrock, J. W. (2007). Perkembangan anak (R. Rachmawati \& K. Kuswanti, Trans.). Erlangga.

Sugiyono, S. (2017). Statistika untuk penelitian. Alfabeta.

Sunarty, K. (2015). Pola asuh orang tua dan kemandirian anak. Edukasi Mitra Grafika.

Sutanto, A. V., \& Andriyani, A. (2020). Positive parenting: Membangun karakter positif anak. PT Pustaka Baru Press.

Widjaja, W. (2019). Pengaruh motivasi belajar terhadap minat berwirausaha siswa SMA XYZ di Jakarta Barat. Jurnal Ilmu Manajemen, 8(2), 37-49. https://doi.org/10.32502/jimn.v8i2.1819

Wijaya, D. (2017). Pendidikan konsumen. Pustaka Pelajar.

Winkel, W. S., \& Hastuti, S. (2004). Bimbingan dan konseling di institusi pendidikan. Media Abadi. 